\title{
Architecture of biomats reveals history of geo-, aqua-, and bio-systems
}

Department of Earth Sciences, Kanazawa University, Kakuma, Kanazawa, Japan 920-1192.

The architecture of hardened biomats in hot springs is a good example of genetic code, which can lead to the understanding of the primitive Earth. Electron-microscope observation of biomats has revealed a variety of mineralized microbial structures of many microorganisms, particularly in and around the living cells of cyanobacteria. Mn and Fe microcrystals are extensively precipitated. Microorganisms encrusted with calcite are also common. Hardened biomats retain the history of geo-, aqua-, and bio-systems in each layer. Biomats will certainly play an important role in future ecosystems as bioremediation.

\section{Introduction}

Soil-water-atmosphere relations represent a closely linked global system. That is the reason why we have to examine integrated geo-, aqua-, and bio-interactions. However, ecosystems even in the surface environment are poorly understood, because the microorganisms are too small to see and too widely separated in the food chain to examine precisely. Furthermore, we know that microorganisms are ubiquitous in soil, water and the atmosphere. Even in the cold high Arctic, microorganisms live on the ice, whereas various microorganisms thrive near hydrothermal vents at a temperature of $100{ }^{\circ} \mathrm{C}$ (Tazaki et al., 1997). We have many experiences in recognizing the presence of abundant biofilms and biomats in aqua systems such as seas, lakes, rivers, hot springs and drainage areas (Fyfe, 1996; Fyfe et al., 1996). Fortunately, we now have the micro-techniques available with which to observe small microorganisms. A study of biomats of bacterial colonies with biominerals is an exciting research area giving a new perspective on ecosystems. Using electron microscopes, we have found that in the aqua system, many minerals are formed in complex bio-mediated processes. The biominerals found in sediments have recorded a long history of geo- and aqua- systems.

\section{Making biomats}

In biomats, many steps of the mineral-forming processes can be traced within the living cells of microorganisms. Beautiful green biomats covering the surfaces of waterfalls contain biominerals produced by cyanobacteria. At hot springs, colored and banded precipitation-formed biomats are common (Figure 1). At different water temperatures, the architecture of biomats assumes different colors. Within the zones of the hottest water, dark-red biomats occur. The color of biomats changes from brown to green with decreasing temperature. At the lower temperature cyanobacteria live in black or green biomats. These bacteria contain chlorophyll (Figure 2). The diameter of filamentous microorganisms is $3-4 \mu \mathrm{m}$ in the black bio-

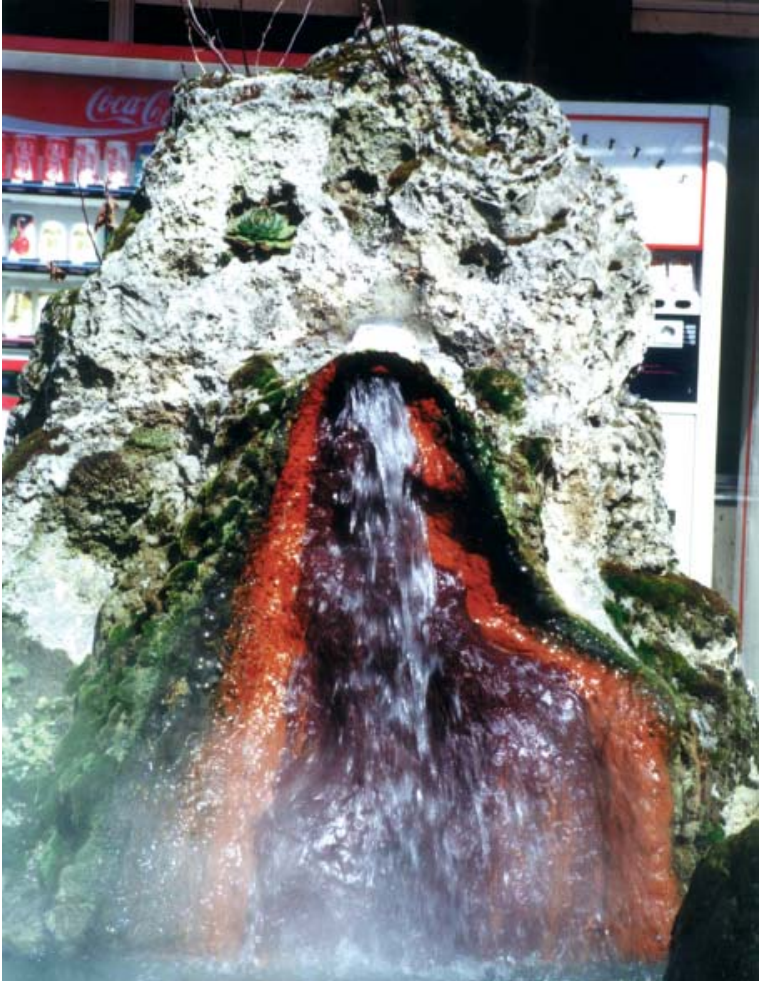

Figure 1 Colorful banded biomats in Hirayu hot springs in Japan, showing various ecosystems at each band with microorganisms forming different biominerals.

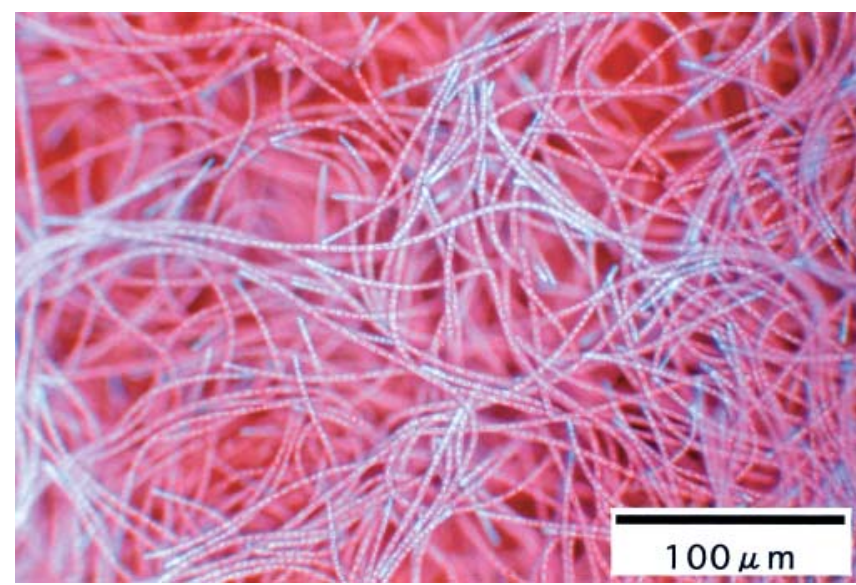

Figure 2 A fluorescence micrograph of filamentous cyanobacteria on the surface of black and green biomats, indicating presence of chlorophyll. The biomats collected from Ogawa hot springs in Japan, contain abundant spherical calcite, around which filamentous bacteria are entangled. 
mats and $1-2 \mu \mathrm{m}$ in the green biomats, which contain S, P, Ca and Fe (Tazaki, 1997). Bacterial biomats are ubiquitous, and play a multitude of important roles in different environments. The bacterial communities are formed by interactions among individuals. Planktonic bacteria assemble on the surface of biomats. Cell-to-cell communication then induces the formation of multicellular pillars and columns (Kolter and Losick, 1998; Davies et al., 1998). Bacteria in nature often exist as sessile communities called biofilms or biomats.

\section{Ecosystem niches of bacteria}

Every bacterium has its own niche in the ecosystem (Ariza, 1998). The Archaea include microorganisms growing in some of the most extreme environments on the Earth. Archean microorganisms which appeared in the early history of the earth are well known (Fyfe, 1997). At the present time the world record for diverse colonies is at a depth of $4.2 \mathrm{~km}$ and a temperature of $110{ }^{\circ} \mathrm{C}$. At hydrothermal vents on the seafloor at great depths and under high water pressure, microorganisms flourish without light (Tazaki et al., 1997; Tawara et al., 1997; Yamamura et al., 1997). The chimneys consist of sulfides, such as sphalerite, pyrite, chalcopyrite, sulfur, and barite. TEM observations led us to the recognition of bacilli $1.0-1.5 \mu \mathrm{m}$ long and $0.3 \mu \mathrm{m}$ wide, which had adsorbed numerous barite particles around the cell wall. Bacteria can also live in very high concentrations of $\mathrm{CO}_{2}$ in the vents. Their cellular components are remarkably stable within a wide range of temperatures, pressures and redox conditions. Danson and Hough (1998) review the structure of archaeal enzymes in the context of their ability to function at extremes of temperature, salinity, $\mathrm{pH}$ and pressure. These communities develop structures that are morphologically and physiologically differentiated from free-living bacteria (Davies, et al., 1998). Certain bacteria, such as the fruiting bacteria, communicate with each other to form structured macroscopic groups.

\section{Making minerals at hot springs}

Near the surface of the earth, hot springs are model systems close to hydrothermal vents, as there are prokaryotic eco-systems in pristine condition. Hot spring biomats are models for past geo-ecosystems which are very important for discussing the past, present and future of the Earth. The extreme conditions are produced by bacteria. Minerals on the primitive Earth could provide a "record" of surfaces for the investigation of pristine geo-ecosystem evolution. Many of classic ore deposits and mining sediments formed in the near-surface environment clearly show the important role of microorganisms. Especially in Iceland (Tazaki and Ishida, 1996; Tazaki, 1997) and Yellowstone National Park in

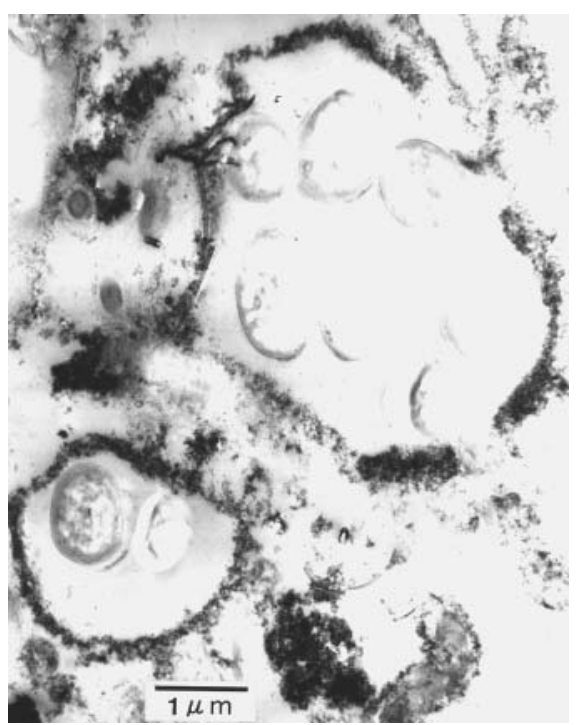

Figure 3 A transmission electron micrograph of ultra thin-sectioned biomats from Lysuholl hot springs in Iceland, showing granular calcite on the surface of living colonies. Several cells of Gloeothece are present in a colony.

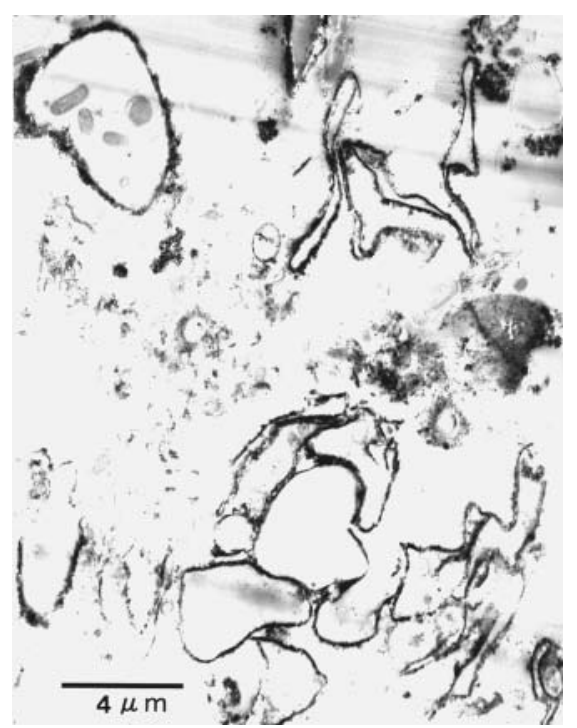

Figure 4 A transmission electron micrograph of Gloeothece in a thinsectioned biomats from Lysuholl hot springs, showing calcite deposition on the surface of colonies. Living cells, which are located inside of encrusted colony, can clearly be seen at left corner, whereas most of the colonies are empty because only calcite crusts are remained after the death of the bacteria. The empty colonies show deformation of crust.
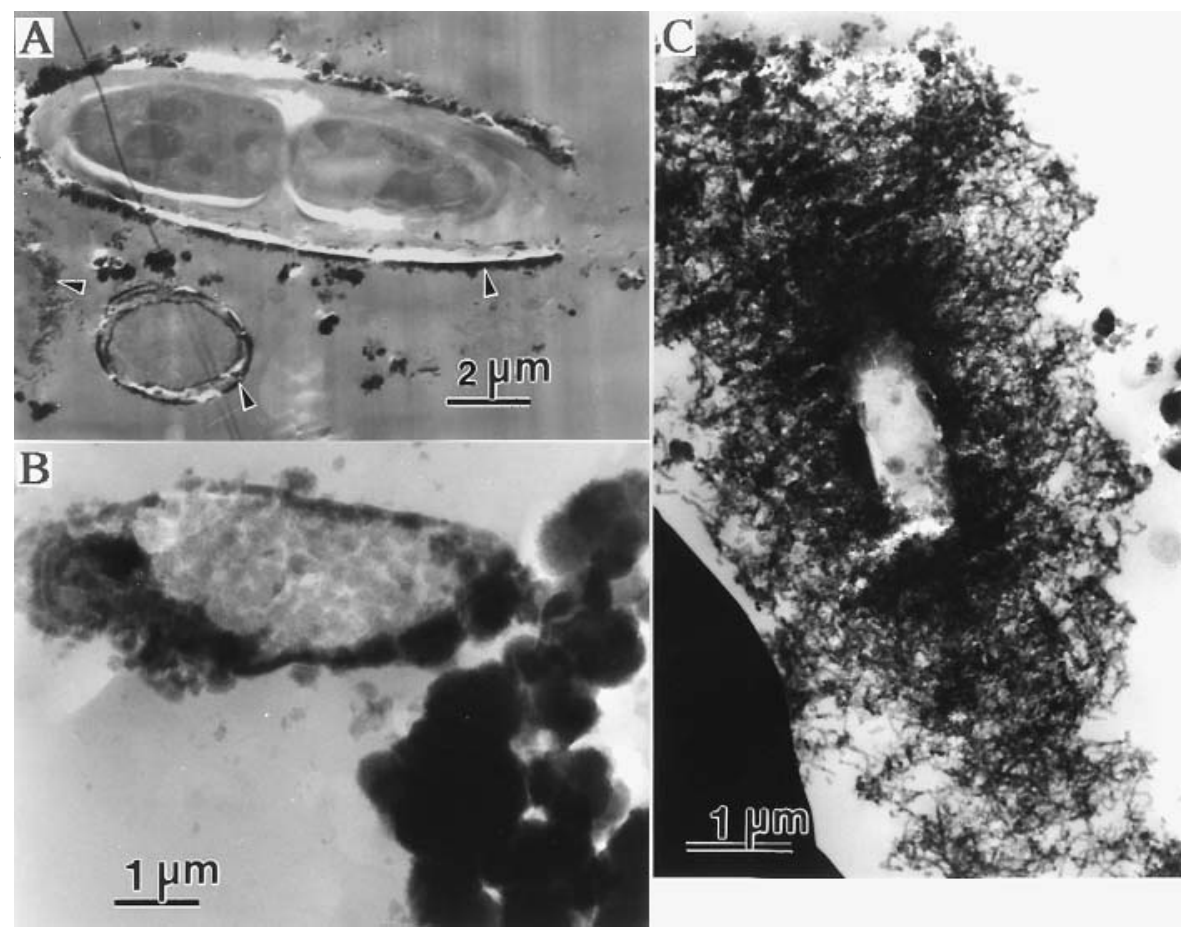

Figure 5 A transmission electron micrographs of a thin-sectioned biomats from Lysuholl hot springs in Iceland, showing precipitation of granular iron minerals on the living cell wall $(A$, arrows), spherical calcite internal and external cell $(B)$ and fibrous Mn minerals are thickly covered on the cell wall $(C)$. In the same eco-system bacteria have established certain symbiotic associations. 
the USA, numerous colorful biomats occur in geo-, aqua- and biosystems, such as hydrothermal areas and hot springs, and contain almost all elements. These hardened biomats form terrace with banded layers which record their water chemistry and ecosystems. One good example is the banded iron formation (BIF) and stromatolite of the Pre-Cambrian ecosystem. Studies of such useful materials shed light on the least-known area of the earth sciences (Tazaki et al., 1997). The architecture of hardened biomats in hot springs is the earth's genetic code.

\section{Biomineralization}

Individual bacterial cells induce elements from aqua-systems, and their colonies in biomats are prominent as nucleation sites for mineral formation. In white biomats of sulfur turf at temperatures of 45-73 ${ }^{\circ} \mathrm{C}$ and $\mathrm{pH} 6-9$, sausage-shaped bacteria accumulate elemental sulfur in S- and O-rich conditions. Several species of bacteria are associated with the sausage-shaped bacteria. Microorganisms are known to influence carbonate mineral formation in a variety of environments from cold to hot spring water in Iceland (Tazaki, 1995), and Japan (Tazaki et al., 1995, 1997). Calcite in hot springs is influenced by microorganisms, in particular cyanobacteria (Figures 3-6). The SEM and TEM micrographs show calcite around the colonies (Figures 3,4) and in or on living cells (Figures 5, 6). The cyanobacterial cell walls offer important nucleation sites for $\mathrm{Ca}$ deposition and the control of ecosystems in the global $\mathrm{CO}_{2}$ cycles. After a bacterium dies, only its carbonate minerals remain and hence the abundant $\mathrm{CO}_{2}$ can be fixed in the sediment.

Biomineralization of $\mathrm{Fe}-\mathrm{Mn}$ oxides at both room temperature and high temperature has also been observed at rivers and hot springs (Figures 7-9). Reddish-brown biomats fill vesicles on the surface of porous basalt near shores with brownish sea water. The beach is stained with reddish seawater, which gives the area the name, "Akayu" (derived from "aka", meaning in Japanese red). $\mathrm{CO}_{2}$ gas is constantly discharged from the beach sand, and colloidal materials are hardened into striped structures (Figure 7). In the pol-

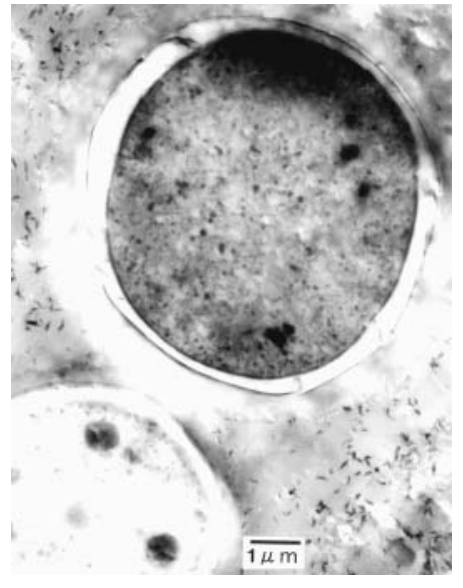

Figure 6 A transmission electron micrograph of a thin-sectioned biomats from Lysuholl hot springs in Iceland, showing large living coccoidal cell with abundant calcite spherules. The external cell wall is clear without any mineralization.

ished thin section, electron microprobe maps show each banded layer to be very thin, typically $<0.1 \mathrm{~mm}$. The brown-red bands are found to be rich in $\mathrm{Fe}_{2} \mathrm{O}_{3}$ and $\mathrm{SiO}_{2}$, whereas the black bands are rich in $\mathrm{MnO}$ and $\mathrm{SiO}_{2}$ (Figures 7, 8). The microorganisms are capable of oxidizing $\mathrm{Fe}$ and $\mathrm{Mn}$. In the biomats, bacteria have established certain symbiotic associations (Tazaki, 1998). This suggests that BIF can be formed in such conditions. The Mn-Fe cycle of depositions may be tidal, daily, seasonal or yearly.

\section{Making geo-biohistory}

On the primitive Earth, with anoxic atmosphere, microorganisms in the primitive sea produced abundant oxygen due to changes in the oxic atmosphere. Danson and Hough (1998) reported the function and stability of enzymes from Archaea which used to live on the primitive Earth. Their cellular components are remarkably stable entities under anoxic conditions. Dead cells of Archaea with their own biominerals may be transferred to deepened biomats. Deep-

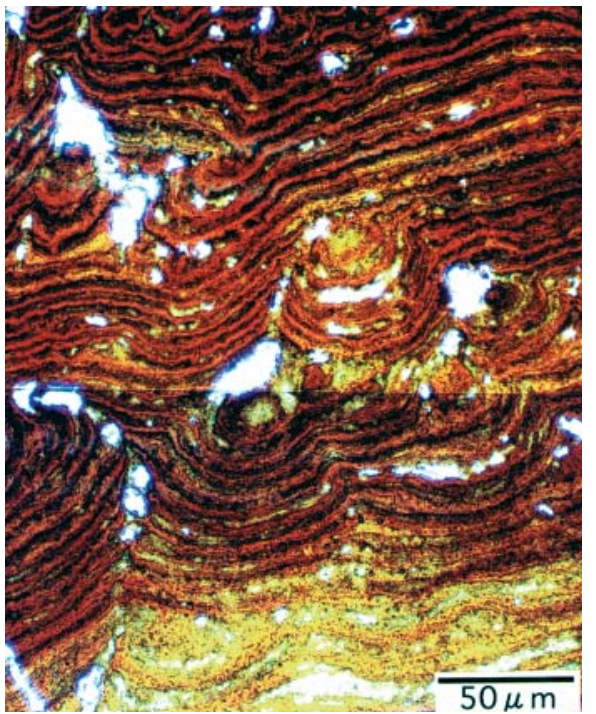

Figure 7 An optical light micrograph of a polished thin-section of reddish brown biomats from Akayu hot springs at Satsuma Iow-Jima Island, Japan. Red and black layers form zonal architecture rich in Fe and Mn. Transmission electron microscopic observations confirm the presence of coccus bacteria in red layers and fibrous or bacillus bacteria in the black layers covered with $\mathrm{Fe}$ and Mn particles.

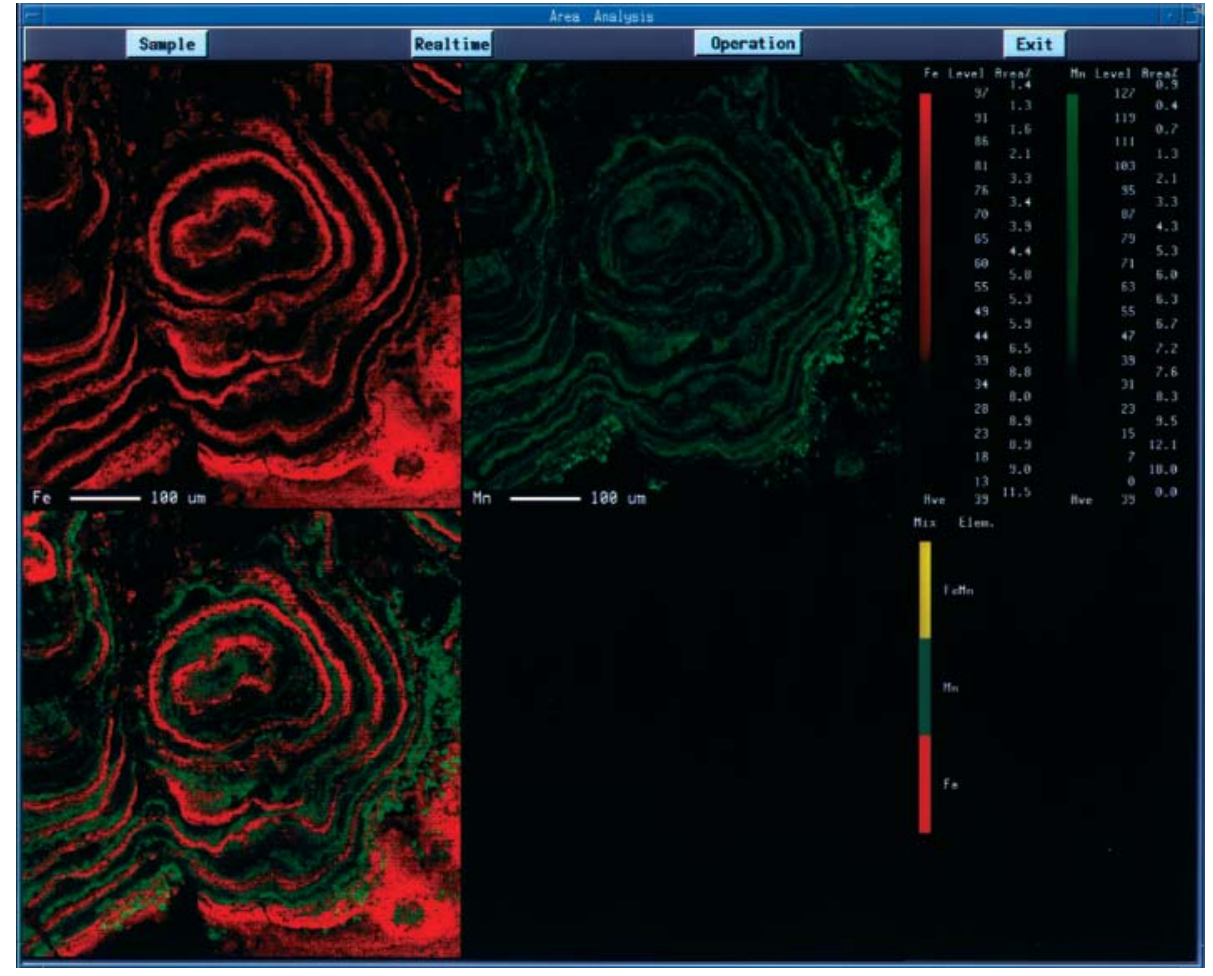

Figure 8 Chemical contents of Fe, Mn, and Fe+Mn maps using electron microprobe analyses of reddish brown biomats from Akayu hot springs at Satsuma Iow-Jima Island, Japan. The Fe+Mn map clearly shows zonal architecture. 


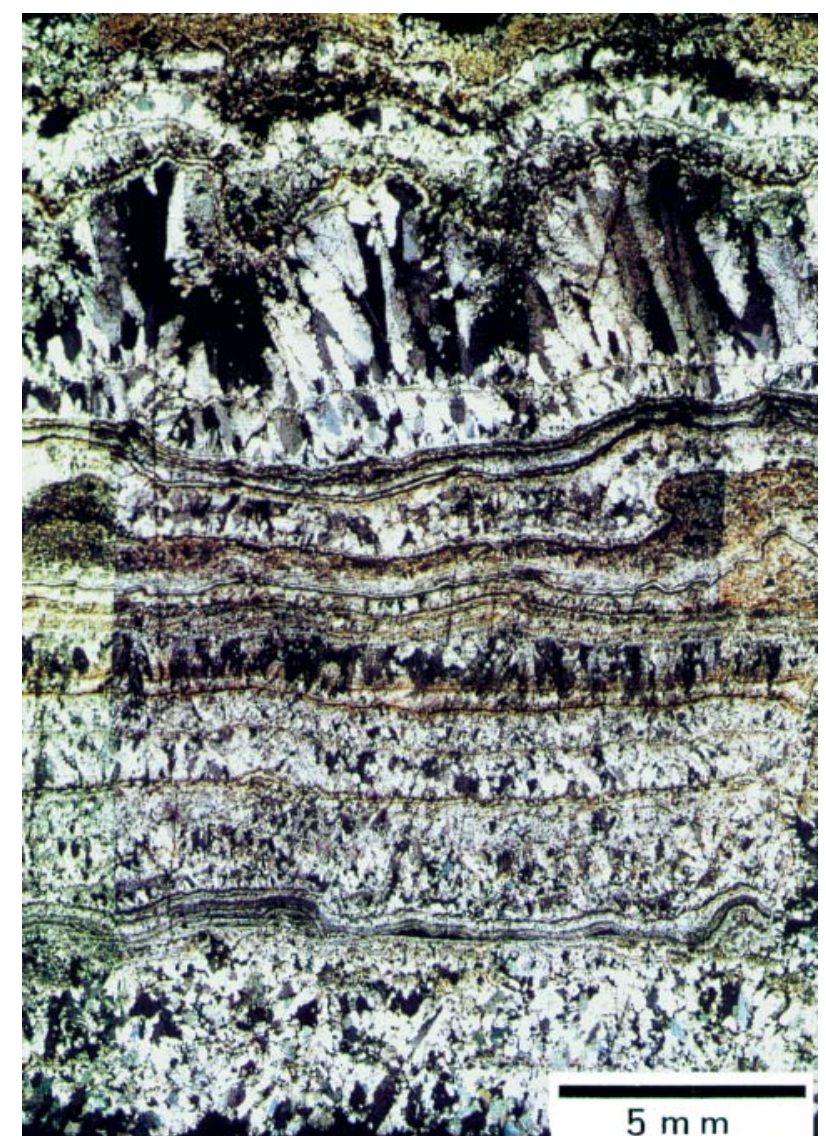

Figure 9 An optical light micrograph of a thin-sectioned biomats from Hirayu hot springs in Japan, showing banded architecture of calcite-rich layers. Each band represents their own history of geo-, aqua- and bioecosystems (Tazaki et al., 1996).

buried and hardened biomats provide a record of environmental history in the sediments. The biomineral layers may not be a homogeneous phase, even when a single aggregate of hardened biomats is examined (Figure 9). These layers contain mainly calcite, but some thin layers are rich in Si, S, and Fe (Tazaki, 1997). The thickness of each layer is different because of the water current, changeable water chemistry and diverse eco-systems of the hot springs. The biominerals reflect the composition of the biological environment in which they are precipitated (Poggi and Skinner, 1998). It is suggested that the formation of the layers is due to tidal, daylight, and seasonal variations, as well as year-long cycles. Biological factors, such as enzymes, hormones and biochemical cycles are also considered. Kolter and Losick (1998) have reported how bacteria form biofilms. Communities are formed by interactions among individuals as "One for all and all for one". Electron micro-morphology and composition of the deposits in hardened biomats show association with other chemical, physical and environmental components.

\section{Bioremediation and future biomat resources}

Understanding symbiosis and biomineralization may help us to understand the development of bioremediation in polluted soil and water (Tazaki, 1996). As regards the versatility of these bacteria in various conditions on mineral substrates, bacterial biomineralization makes them good candidates for fixing toxic metal ions. It is the responsibility of modern geologists to be concerned about mining pollution, and to contribute to cleaning up the earth for future generations. Microorganisms in biomats can be used for bioremediation and rehabilitation in the heavy-metal-contaminated areas. Algae can be used to extract gold, instead of using poisonous mercury, as in traditional mining systems.

Some lower plants such as lichens and mosses can also be used to help to clean up contaminated mining areas. We can use microorganisms for secondary recovery of rare metals from mine wastes. Biomineralization by bacteria needs a very wide range of major and trace metals. They selectively concentrate different heavy metals in the same eco-system, and make certain symbiotic associations.

We have examined how to clean up seriously polluted ground water with $\mathrm{Cd}$ and As. The high Cd concentration in the Jinzu River from the Kamioka Mine in Japan, due to Itai-Itai- disease at Toyama, is still found downstream (Hata, 1996). The water shows high concentrations of $\mathrm{Pb}, \mathrm{Cd}, \mathrm{Fe}, \mathrm{Zn}$ and $\mathrm{Cu}-23 \mathrm{ppb}, 3.1 \mathrm{ppb}, 10 \mathrm{ppm}$, $0.12 \mathrm{ppm}$ and $25 \mathrm{ppb}$, respectively (Tazaki et al., 1998). Bacteria (Gallionella, an iron bacterium) in the biomats absorb abundant $\mathrm{Fe}^{2+}$ to form lepidocrocite, whereas lower plants, such as Athyrium yokoscens, absorb $\mathrm{Cu}, \mathrm{Pb}$ and $\mathrm{Zn}$ (Aoki, et al., 1997; Aoki and Tazaki, 1998; Nishida and Tazaki, 1997). In a laboratory experiment using mining waste and slag containing high $\mathrm{Cd}$, it was shown that green algae can absorb abundant $\mathrm{Cd}$ from the solution within one month (Matsumoto et al., 1998). Green algae in a tailing pond also accumulated high $\mathrm{Cd}$ in living cells. The findings indicate that biomineralization can be applied to bioremediation. Furthermore, biomats can be linked to the following "4 Rs": recovery of healthy water and soils, resource of useful microorganisms, reuse of accumulated heavy metals, and recycling of biominerals.

\section{Conclusions}

Microorganisms exist everywhere under anaerobic and aerobic conditions. They can survive in extreme environmental conditions in geo- and aqua-systems. Every bacterium has its own niche for making minerals. The dead bacteria leave their mineralized cells in the sediments. Hardened biomats provide a record of the earth's history. Microorganisms are capable of oxidizing $\mathrm{Fe}$ and $\mathrm{Mn}$. Fe- and $\mathrm{Mn}$ bacteria have established certain symbiotic associations; understanding this symbiosis could help us to understand the development of early life on the earth. The microscopic observations of architecture of hardened biomats in hot springs are a good way to understand the primitive earth, as they provide genetic earth codes. Furthermore, in the point of view of the "4Rs", the versatility of these bacteria can be used for bioremediation in polluted areas. The biomats certainly play an important role, not only in the past and present, but also in future ecosystems.

\section{Acknowledgments}

This research was supported by the Japanese Natural Science Foundation. I thank Dr. Kozo Takahashi, Kyushu University, for reading the manuscript.

\section{References}

Ariza, L.M.,1998, River of Vitriol: Scientific American,Sept. pp.15-18.

Aoki, A., Matsumoto, K., Nishida, S. and Tazaki, K., 1997, Environmental investigation of heavy metals pollution along Jinzu River in Toyama Pre., Japan.: Abstract for 11th Inter. Clay Cog. in Ottawa, pp. A4.

Aoki, A. and Tazaki, K., 1998, Bioremediation by Gallionella at mining area polluted by heavy metals: Abstract of 17th Inter. Miner. Asso. Meeting, pp. A74.

Danson, M.J. and Hough, D.W., 1998, Structure, function and stability of enzymes from the Archaea: Trends in Microbiology, v. 6, pp.307-314.

Davies, D.G., Parsek, M.R., Pearson, J.P. and Greenberg, E.P., 1998, The involvement of cell-to-cell signals in the development of a bacterial biofilm. Science, v.280, pp.295-297.

Fyfe, W.S., 1996, The biosphere is going deep: Science, v.273, pp. 448. 
Fyfe, W.S., Leveille, W., Zang, W. and Chen, Y., 1996, Is $\mathrm{CO}_{2}$ disposal possible?: Preprints of 212th ACS National Meeting, Orlando, FL, v. 41, pp. 1433-1435.

Fyfe, W.S., 1997, The Earth Sciences and Society: The needs for the 21st century: Proc. 30th Int'1. Geol. Congr. v. 2\&3,pp. 147-162.

Hata, A., 1996, Pollution prevention of the Kamioka Mine and refinery after the "Itai-Itai disease suit": Osaka Univ. Business Review, No.7, pp.1-15.

Kolter, R. and Losick R., 1998, One for all and all for one: Science, v.280, pp. 226-227.

Matsumoto, K., Aoki, A. and Tazaki, K., 1998, Bioremediation of heavy metals at polluted water system: Abstract for Japan Earth and Planetary Science Joint Meeting, Tokyo, pp. 191.

Nishida, S. and Tazaki, K., 1997, The experimental water purification by plant; purification of the polluted water with heavy metals: Annual Rep. of Botanical Garden, Kanazawa Univ., v. 20, pp. 19-30.

Poggi, S.H. and Skinner, H.C.W., 1998, Using scanning electron microscopy to study biological mineral deposits: Abstract of 17th Inter. Miner. Asso. Meeting, pp. A64.

Tawara, K., Yamamura, T., Tazaki, K., Chiba, H. and Ishibashi, J., 1997, Microorganisms of hydrothermal vents at Iheya Ridge: Mineralogical J. of Japan, v.26, pp.81-85

Tazaki, K.,1995, Electron microscopic observation of biomineralization in biomats from hot springs: Jour. Geol. Soc. Japan, v.101, pp. 304-314.

Tazaki, K., Ishida, H. and Fyfe, W.S.,1995, Calcite deposition in a hot spring microbial mat from Iceland: Proceedings of Inter. Clay Cong. in Australia, pp. 30-37.

Tazaki, K., 1996, Environmental biomineralization and microbial remediation: Shigen-to-Sozai, v. 112, pp. 827-835.

Tazaki, K. and Ishida, H.,1996, Bacteria as nucleation sites for authigenic minerals: Jour. Geol. Soc. Japan, v.102, pp.866-878.

Tazaki, K., Yamamura, T., Nagai, H. and Koiwasaki, K., 1996, Formation of banded structure by bacteria: CHIKYU MONTHLY, v. 18, pp.9-17.

Tazaki, K.,1997, Biomineralization of layer silicates and hydrated Fe/Mn oxides in microbial mats: An electron microscopical study: Clays and Clay Miner., v. 45, pp. 203-212.
Tazaki, K. (Ed.), 1997, Microbial mats in Japan; Microbial biomineralization: pp.1-91.

Tazaki, K., Aoki, A., Asada, R. et al., 1997, A new world in the science of biomineralization; Environmental biomineralization in microbial mats in Japan: Science Rep. of Kanazawa Univ., v.XLII, pp.1-65.

Tazaki, K., 1998, A recent BIF showing bacterial rings: Abstract of 17th Inter. Miner. Asso. Meeting, pp. A72.

Tazaki, K., Aoki, A. and Matsumoto, K., 1998, Heavy metal pollution and environmental Earth sciences: Proceeding of 2 nd Inter. Itai-Itai disease Symp., in press.

Yamamura, T., Tawara, K., Tazaki, K., Chiba, H. and Ishibashi, J., 1997, Needle-like minerals at Iheya Ridge: Mineralogical J. of Japan, v.26, pp.113-116.

Kazue Tazaki is the chairperson of the Department of Earth Sciences in Kanazawa University, and the vice president of the Japanese Clay Association. She cooperated with Professor W.S. Fyfe in University of Western Ontario, Canada from 19841989. She is mainly interested in environmental earth sciences and biomineralization using Electron Microscopical techniques. Currently she is supervising nearly thirty graduates and undergraduate students.

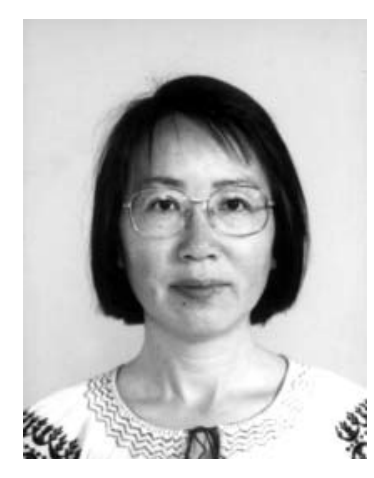

\title{
Hutchison 'Young Scientist' Fund
}

William Watt Hutchison, "Hutch" to his many friends around the world, was a Scots-born Canadian geologist who served Canada and the IUGS in myriad dynamic and creative ways. Most notably, he served as the IUGS Secretary General (1976-1980) at a pivotal time in its history, and as IUGS President (1984-1987). The same boundless energy, enthusiasm, skill in communications, and ability to foster teamwork that characterized his work with the IUGS also carried him to preeminent scientific administrative positions in the Canadian Government, where he served as Director General of the Geological Survey of Canada and as Assistant Deputy Minister of Earth Sciences. His distinguished career was terminated in 1987 by his untimely death at the age of 52, following a painful struggle with cancer.

One of Hutch's last wishes was to establish under IUGS auspices a memorial foundation intended to promote the professional growth of deserving, meritorious young scientists from around the world by supporting their participation in important IUGS-sponsored conferences. The first 3 beneficiaries of the Hutchinson "Young Scientist Foundation" attended the 28th International Geological Congress (IGC) in Washington, D.C., in 1989.

Currently, income earned as interest on the Hutchison fund is insufficient to sustain comparable grants every four years without seriously eroding the principal. For that reason, the IUGS made no grants from the fund for the 30th IGC, preferring instead to strengthen the fund by allowing it to earn interest for a longer period of time and by appealing for donations from the international geologic community. It is expected that grants from the fund will again support deserving young scientists to attend the 31st IGC in the year 2000. The Hutchison "Young Scientist Foundation" is a worthy cause that honors a fine, caring man and a distinguished, public-spirited scientist and administrator. The foundation also celebrates and promotes those things that gave Hutch the most professional satisfaction: geology, international scientific collaboration, and stimulating young minds.

The IUGS welcomes contributions to the Hutchison "Young Scientist Foundation." Please send donations to:

\author{
Dr. John A. Reinemund \\ P.O. Box 890 \\ Leesburg, VA 20178 USA \\ Fax: +17037774463 \\ Tel: +17037771491
}

Checks in US dollars or Visa/Mastercard (please include account number and expiration date) are preferred in order to avoid the high cost of currency conversions. Residents of the U.S.A. are reminded that charitable gifts of this nature are tax deductible. 